\title{
PROMOSI KESEHATAN DENGAN PEMBERIAN REBUSAN DAUN SELEDRI UNTUK MENURUNKAN TEKANAN DARAH PADA WANITA MENOPAUSE
}

\author{
Diah Evawanna Anuhgera ${ }^{*}$, Riris Sitorus ${ }^{2}$, Nikmah Jalilah Ritonga ${ }^{1}$, \\ Juni Mariati Simarmata ${ }^{3}$, Novita Ginting Munthe ${ }^{2}$ \\ ${ }^{1}$ Program Studi Sarjana Kebidanan, Institut Kesehatan Medistra Lubuk Pakam
2Program Studi D-III Kebidanan, Institut Kesehatan Medistra Lubuk Pakam
${ }^{3}$ Program Studi D-III Keperawatan, Institut Kesehatan Medistra Lubuk Pakam
}

JIn. Sudirman No.38 Lubuk Pakam, Kabupaten Deli Serdang,

Sumatera Utara - Indonesia

*email korespondensi author: diah.evawanna@gmail.com

DOI $10.35451 /$ jpk.v1i1.727

\begin{abstract}
Abstrak
Hipertensi merupakan penyakit kronik yang sering mengakibatkan komplikasi terhadap organ tubuh lainnya. Berdasarkan penemuan bukti terkini bahwa pemberian rebusan daun seledri dapat menurunkan tekanan darah. Kegiatan promosi kesehatan melalui pemberian rebusan daun seledri dapat dijadikan alternatif dalam mensosialisasikan pencegahan dan penanganan secara dini pada kasus hipertensi yang sering terjadi pada wanita menopause. Tujuan pengabdian masyarakat ini yaitu meningkatkan kualitas hidup dari wanita menopause dengan membantu menurunkan tekanan darah secara non farmakologi serta mengurangi efek samping yang dirasakan pada wanita hipertensi. Pemberian rebusan daun seledri dapat diberikan satu kali dalam sehari secara teratur. Pelaksanaan pengabdian masyarakat ini berlangsung selama 2 hari di Kantor Kepala Desa Sidodadi Ramunia Kecamatan Beringin Deli Serdang. Kegiatan ini diawali dengan melakukan pemeriksaan rapid test kepada semua responden lalu diikuti pemeriskaan tekanan darah sebelum pelaksanaan promosi kegiatan. Pada hari kedua pelaksanaan, setiap responden dilakukan pengukuran tekanan darah untuk melihat penurunan tekanan darah pada setiap responden. Hasil pemeriksaan tekanan darah dari 32 responden terdapat penurunan tekanan darah sisitolik sebanyak 32 orang (100\%) dan penurunan tekanan darah diastolik sebanyak 28 orang (81,25\%). Pemberian rebusan daun seledri dapat bermanfaat bagi wanita hipertensi untuk menurunkan dan mengontrol tekanan darah.
\end{abstract}

Kata kunci: promosi kesehatan, daun seledri, tekanan darah, hipertensi

\begin{abstract}
Hypertension is a chronic disease that often results in complications for other organs. Based on the findings of recent evidence that giving celery leaf decoction can lower blood pressure. Health promotion activities through the provision of celery leaf stew can be used as an alternative in promoting early prevention and treatment of hypertension cases that often occur in menopausal women. The goal of this community service is to improve the quality of life of menopausal women by helping to lower blood pressure non-pharmacologically and reducing the side effects felt in women with hypertension. Celery leaves stew can be given once a day on a regular basis. The implementation of this community service lasted for 2 days at the Head Office of Sidodadi Ramunia Village, Beringin Deli Serdang District. This activity begins with conducting a rapid test for all respondents, followed by a blood pressure check before the promotion of the activity. On the second day of implementation, each respondent took blood pressure measurements to see the decrease in blood pressure
\end{abstract}


Received: 07 June 2021 :: Accepted: 15 June 2021 :: Published: 30 June 2021

for each respondent. The results of blood pressure examinations from 32 respondents showed a decrease in sysitolic blood pressure by 32 people $(100 \%)$ and a decrease in diastolic blood pressure by 28 people $(81.25 \%)$. Celery leaves decoction can be useful for hypertensive women to lower and control blood pressure.

Keywords: health promotion, celery leaves, blood pressure, hypertension

\section{Pendahuluan}

Hipertensi merupakan faktor resiko utama yang dapat diakibatkan oleh penyakit kardiovaskuler (CVD) dan kematian dini di Indonesia dan seluruh dunia. Berdasarkan literatur dari studi observasional menunjukkan hubungan yang kuat dan positif antara tekanan darah dan resiko penyakit kardiovaskuler dan kematian. Hasil studi uji klinis telah membuktikan bahwa pengobatan hipertensi mengurangi kematian secara dini pada penderitanya (Mezeyova et al, 2018).

Hipertensi yang merupakan silent killer dapat dilihat dari tahap awal hingga akhir yang sering terjadi dan banyaknya masyarakat yang kurang menyadari peningkatan tekanan darah yang berlebihan dan pendeteksian yang dilakukan hanya sebatas pada pengukuran (Moradi et al, 2016). Mayoritas pasien menderita hipertensi asimtomatik dan beberapa orang dengan hipertensi melaporkan sakit kepala, vertigo, penglihatan berubah, dan pingsan (Bogdanski, 2012).

Prevalensi kematian yang diakibatkan oleh hipertensi terjadi 7,5 juta atau $12,8 \%$ dari total semua kematian di seluruh dunia dan hal ini diperkiran meningkat menjadi 1,56 miliar orang dewasa dengan hipertensi di tahun 2025. Berdasrkan Riset Kesehatan Dasar (Riskesdas) pada tahun 2018 terdapat kejadian hipertensi sebanyak 25,8\% (Kemenkes, R. I, 2018)

Pedoman American College of Cardiology/American Heart Assocoation (ACC/AHA) 2017 untuk pencegahan, deteksi, evaluasi dan manajemen tekanan darah tinggi pada dewasa merekomendasikan ambang batas yang lebih rendah dibandingkan dengan pedoman sebelum nya yaitu tekanan darah sistolik $\geq$ atau tekanan darah diastolik $\geq$ (Mezeyova et al, 2018).

Peningkatan kasus hipertensi terjadi diakibatkan oleh modifikasi gaya hidup, dan aktivitas fisik. Selain itu berdasarkan survey awal yang dilakukan oleh tim pelaksana bahwa ada beberapa faktor yang menyebabkan tingginya hipertensi yakni ada perbedaan antara wilayah perkotaan dan pedesaanyang sering dikaitkan dengan urbanisasi Kesehatan.

Pengobatan sederhana yang dapat dilakukan pada wanita yang menderita hipertensi yakni dengan mengkonsumsi rebusan daun seledri secara teratur. Seledri mengandung aromatik yang kuat pada batang dan daun. Kandungan minyak esensial serta flavonoidnya pada seledri mengandung antioksidan, antijamur, antibakteri dan menurunkan tekanan darah. Beberapa penelitian telah menunjukkan efek dari pemberian seledri dapat digunakan sebagai pengobatan non farakologi dalam hipertensi tingkat I dan II (Anuhgera, D. E, 2020)

Tujuan dari pelaksanaan pengabdian masyarakat dengan judul promosi kesehatan dengan pemberian rebusan daun seledri untuk menurunkan tekanan darah pada wanita menopause adalah untuk menjaga kualitas kesehatan dari para wanita hipertensi yang sudah menopause melalui pemberian promosi kesehatan mengenai hipertensi dan penangan sederhana hipertensi melalui pemberian rebusan daun seledri secara sederhana. Hal ini dapat dikonsumsi agar menjaga kestabilan kesehatan dari wanita menopause yang sering mengalami komplikasi penyakit degenaratif di masa menopause. Lokasi pengabdian masyarakat ini dilaksanakan di kantor kepala desa Ramunia Kecamatan Beringin Deli Serdang. 


\section{Metode}

Metode pelaksanaan pengabdian masyarakat dimulai dari pendataan lokasi pada wanita menopause yang mengalami hipertensi tipe I dan II di Desa Sidodadi Ramunia Kecamatan Beringin Deli Serdang, setelah dilakukan

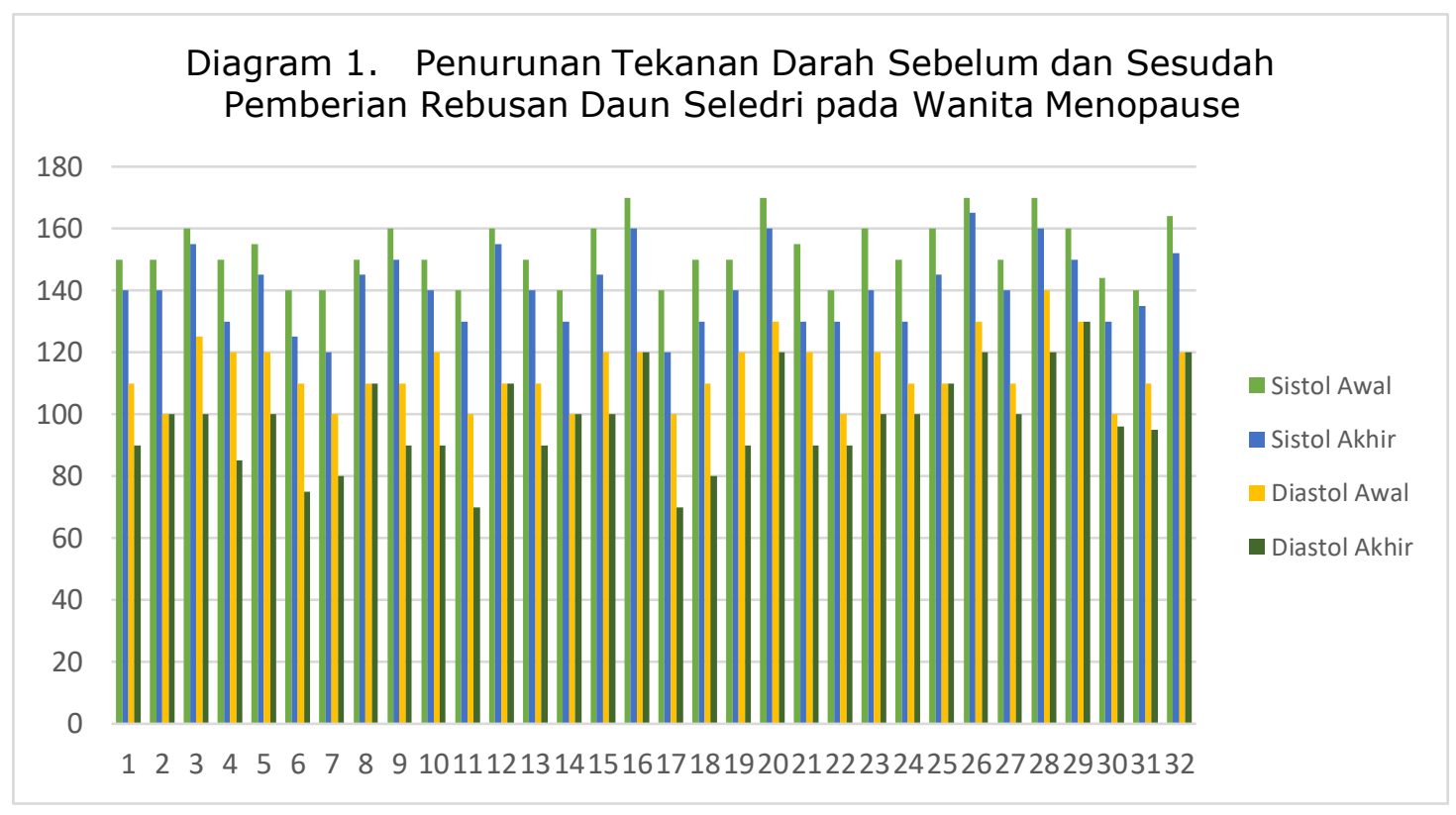

pendataan maka dilakukan pemeriksaan rapid test untuk mendeteksi terjadinya penularan kasus COVID-19 dan melakukan pemeriksaan tekanan darah meliputi sistolik $(>140 \mathrm{mmHg})$ dan diastolik $\quad(<90 \quad \mathrm{mmHg}) \quad$ kepada masyarakat. Sebelum pemberian rebusan daun seledri maka dilakukan penyuluhan edukasi mengenai hipertensi, komplikasi hipertensi dan penanganan hipertensi secara non farmakologi dengan menggunakan rebusan daun seledri beserta pemberian leaflet mengenai. Demonstrasi penyajian rebusan daun seledri dilakukan secara langsung beserta leaflet mengenai penggunaan jumlah takaran bahan yang digunakan agar dapat diaplikasikan di rumah oleh mitra kerja. Wanita menopause yang mengikuti sosialisasi diberikan 1 gelas rebusan daun seledri untuk dapat dikonsumsi saat penyuluhan. Pelaksana kegiatan juga melakukan diskusi dan tanya jawab kepada masyarakat dan melakukan posttest setelah selesai melakukan sosialisasi.

Bahan-bahan yang digunakan selama pelaksanaan yaitu 100 gram daun seledri ( \pm 8 tangkai daun seledri), dan air $400 \mathrm{ml}$. Semua bahan direbus selama 10 menit lalu didinginkan dan dapat dikonsumsi 1 kali dalam sehari. Pengukuran tekanan darah menggunakan spignomanometer air raksa yang telah dikalibrasi.

\section{Hasil dan Pembahasan}

Pelaksanaan dilakukan kepada seluruh wanita yang mengalami hipertensi di Desa Sidodadi Ramunia Kecamatan Beringin Deli Serdang. Kegiatan ini dilaksanakan pada tanggal 9- 10 Mei 2020 pada hari Sabtu dan Minggu di Kantor Kepala Desa Ramunia Kecamatan Beringin Kabupaten Deli Serdang sejumlah 32 orang.

Hasil pemeriksaan tekanan darah sistolik pada 32 wanita menopause pada hari kedua mengalami penurunan sebanyak 32 orang (100\%) dengan rerata penurunan diastolik sebesar $11,65 \mathrm{mmHg}$ dan penurunan untuk tekanan diastolik sebanyak 26 orang $(81,25 \%)$ dengan rerata penurunan sebesar 15,75 mmHg. Hal ini menunjukkan bahwa pemberian rebusan daun seledri dapat membantu menurunkan tekanan darah pada wanita menopause.

Kegiatan ini dilakukan selama 2 hari. Pada hari pertama tim pelaksana 
Received: 07 June 2021 :: Accepted: 15 June 2021 :: Published: 30 June 2021

melakukan promosi kesehatan mengenai hipertensi dan pemberian rebusan daun seledri sedangkan hari kedua dengan melakukan pemberian rebusan daun seledri serta melakukan pengecekan tekanan darah setelah pemberian rebusan daun seledri.

Pengabdian masyarakat melalui promosi kesehatan dilakukan dengan menyampaikan informasi melalui demonstrasi dan leaflet yang dibagikan kepada responden. Para responden juga diberikan kesempatan untuk bertanya dan meredemonstrasi pembuatan dari rebusan daun seledri. Respon responden ketika dilakukan promosi kesehatan dapat terlihat aktif dari kesediaan para responden yang aktif bertanya dan mendengarkan penyampaian informasi dari tim pelaksana dengan baik.

Mekanisme Kerja dari rebusan seledri sehingga dapat digunakan untuk menurunkan tekanan darah karena seledri memiliki kandungan senyawa fenolik dan memiliki efek antioksidan. Senyawa flavonoid akan menghambat ACE (Angiotension Converting Enzyme) yang dapat mencegah hipertensi (Widyani, 2019). Penghambat ACE ini juga tersedia pada obat-obatan yang digunakan dalam pengobatan hipertensi. Seledri yang memiliki kandungan antioksidan yang tinggi akan melawan radikal bebas dan menurunkan stress oksidatif sehingga menimbulkan efek hipotensi (Obaroh, U. J, 2018)

\section{Kesimpulan}

Pemberian rebusan daun seledri merupakan salah satu terapi sederhana secara farmakologi untuk menurunkan dan mengontrol tekanan darah. Berdasarkan pengukuran tekanan darah pada wanita menopause sebanyak 34 orang. Mayoritas responden terdapat penurunan tekanan kepada wanita menopause yang mengikuti promosi kesehatan pada pertemuan ini.

Responden mengerti akan sosialisasi yang diberikan dengan baik dan diharapkan akan ada kegiatankegiatan yang bermanfaat dalam kesehatan

\section{Ucapan Terima Kasih}

Ucapan kepada Kepala Desa
disampaikan kepasiha
Ramunia Kecamatan Beringin, Deli
Serdang, kepada Institut Kesehatan
Medistra Lubuk Pakam dan seluruh
masyarakat desa Sidodadi Ramunia
yang telah membantu alam
melaksanakan proses pengabdian
masyarakat.

\section{Daftar Pustaka}

Anuhgera, D. E., Yolanda, R., Sitorus, R., \& Ritonga, N. J. (2020). Pengaruh Pemberian Rebusan Daun Seledri (Apium Graveolens L) Terhadap Tekanan Darah Pada Wanita Menopause Dengan Hipertensi. Jurnal Kebidanan Kestra (JKK), 3(1), 67-74.

Badrujamaludin, A., Budiman, B., \& Erisandi, T. D. (2020). Perbedaan air rebusan daun seledri dan air rebusan daun salam terhadap penurunan tekanan darah pada pra lansia dengan hipertensi primer. Holistik Jurnal Kesehatan, 14(2), 177-186.

Bogdanski, P., Suliburska, J., Szulinska, M., Stepien, M., Pupek-Musialik, D., \& Jablecka, A. (2012). Green tea extract reduces blood pressure, inflammatory biomarkers, and oxidative stress and improves parameters associated with insulin resistance in obese, hypertensive patients. Nutrition research, 32(6), 421427.

Kemenkes, R. I. (2018). Hasil Utama Laporan Riskesdas 2018. Jakarta: Kementerian Kesehatan Republik Indonesia.

Mezeyova, I., Hegedűsová, A., Mezey, J., Šlosár, M., \& Farkaš, J. (2018). Evaluation of quantitative and qualitative characteristics of selected celery (Apium graveolens var. dulce) varieties in the context of juices production. Potravinarstvo, 12(1).

Moradi, M. T., Asadi-Samani, M., \& Bahmani, M. (2016). Hypotensive medicinal plants according to Ethnobotanical evidence of Iran: A Systematic Review. International 
Received: 07 June 2021 :: Accepted: 15 June 2021 :: Published: 30 June 2021

Journal of PharmTech Research, 9(5), 416-426.

Widyani, R. (2019). Potency of Herbal Plants Formulation as Anticholesterole agent: In Vitro Studies. Systematic Reviews in Pharmacy, 10(2), 253-258.

Obaroh, U. J. (2018). Nonpharmacological Interventions in the Management of Hypertension (Doctoral dissertation, Brandman University). 